NBER WORKING PAPER SERIES

\title{
EVALUATION OF EXCHANGE-RATE, CAPITAL MARKET, AND DOLLARIZATION REGIMES IN THE PRESENCE OF SUDDEN STOPS
}

\author{
Assaf Razin \\ Yona Rubinstein \\ Working Paper 11131 \\ http://www.nber.org/papers/w11131
NATIONAL BUREAU OF ECONOMIC RESEARCH
1050 Massachusetts Avenue
Cambridge, MA 02138
February 2005

We thank two referees for insightful comments. We acknowledge useful discussions on the topics of the paper with Marianne Baxter, Giancarlo Corsetti, Alex Cukierman, Allan Drazen, Alejandro Izquierdo, Gian Maria Milesi-Ferretti, Ady Pauzner, and Dan Trefler. We are indebted to Gian Maria Milesi-Ferretti, Carmen Reinhart, Federico Sturzenegger, and Romain Ranciere, for providing us with various data sets. We thank Yaniv Yedid Levy for competent research assistance. The views expressed herein are those of the author(s) and do not necessarily reflect the views of the National Bureau of Economic Research.

(C) 2005 by Assaf Razin and Yona Rubinstein. All rights reserved. Short sections of text, not to exceed two paragraphs, may be quoted without explicit permission provided that full credit, including $\odot$ notice, is given to the source. 
Evaluation of Exchange-Rate, Capital Market, and Dollarization Regimes in the Presence of Sudden Stops Assaf Razin and Yona Rubinstein NBER Working Paper No. 11131

February 2005

JEL No. F4

\begin{abstract}
$\underline{\text { ABSTRACT }}$
The literature has not being able to identify clear-cut real effects of exchange-rate regimes on output growth. Similarly, no definitive view emerges from the literature in regard to the effects of open capital markets on macroeconomic performance. The paper attributes the failure of the literature to fundamental flaws, consisting of ignoring non-linearities in the effects of exchange rate and capitalmarket liberalization regimes, on the macroeconomic performance. The paper develops a methodology consisting of accounting for the "“"crisis-prone state of the economy"”, summarized by a projected probability of crisis, due to sudden stops in international capital inflows. We apply the new methodology to a cross-country panel of 100 low and middle-income countries. Findings indicate that the effects of exchange rate regimes, and liberalization regimes, on macroeconomic performance go through two distinct channels: a direct channel via the real side of the economy, and an indirect channel via the financial side, which influences the probability of sudden stops. We also analyze how the projected probability of sudden stops affects the level of dollarization, and provide estimates for the effect of dollarization on growth.
\end{abstract}

\author{
Assaf Razin \\ Eitan Berglas School of Economics \\ Tel Aviv University \\ Tel Aviv 69978 \\ ISRAEL \\ and NBER \\ razin@post.tau.ac.il \\ Yona Rubinstein \\ Tel Aviv University \\ yonar@post.tau.ac.il
}




\section{INTRODUCTION}

The choice of macroeconomic policies is traditionally cast in terms of the well-known trilemma. This is a way of describing succinctly a choice among three policy goals: pegging the exchange rate, keeping the capital markets open, or conducting a business-cycle stabilizing monetary policy. The tri-lemma arises because only two of these policy goals can be achieved at any point of time. But often there is an additional policy goal: keeping the economy out of sudden stops to international capital flows, or other violent types of financial crises. $^{2}$ The literature, however, often ignores this aspect of the policy-regime choice problem.

We challenge two established puzzles in the international macroeconomics. The first puzzle is the failure of the literature to find any systematic difference in the macroeconomic process across exchange rate regimes. The second is the absence of any empirical relation between macroeconomic performance and capital-account liberalization. We attribute the failure of the literature to address these puzzles to a fundamental flaw. It consists of ignoring nonlinearities in the effect of exchange-rate regimes, and capital-account liberalization regimes, on macroeconomic performance. Specifically, the literature ignores a latent crisis state of the economy, which is summarized by an estimated probability of crisis. Our analysis focuses on the evaluation exchange rate regimes and capital-market liberalization regimes, in the presence of sudden stops.

\footnotetext{
${ }^{2}$ In fact, therefore, the policy choice problem is a Polly-lemma; rather than a Tri-lemma.
} 
Macroeconomic theory has long recognized that there exist positive effects of the exchange rate peg regime on macroeconomic performance. The idea is that by fixing their currencies to international moneys (the dollar, the euro, or the yen), fiscally-disciplined emerging economies, could rapidly accumulate exchange reserves through export growth, and maintain a high saving ratio, which would provide certainty to business and profit margins to investors. Such a policy environment leads to a low and stable domestic rate of interest, and thus enables the economy to retain the confidence of international investors.

However, every major international economic crisis of the past 15 years (save Brazil in 2002) has been rooted in rigid exchange rate regimes. As Stanley Fischer (2001) succinctly observed: "Each of the major international capital market-related crises since 1994--Mexico, in 1994, Thailand, Indonesia and Korea in 1997, Russia and Brazil in 1998, and Argentina and Turkey in 2000--has in some way involved a fixed or pegged exchange rate regime. At the same time, countries that did not have pegged rates--among them South Africa, Israel in 1998, Mexico in 1998, and Turkey in 1998--avoided crises of the type that afflicted emerging market countries with pegged rates."

Indeed, there has been a long-standing view that an emerging economy under a peg, with government budget imbalances, trade deficits, and the presence of free-market policies that facilitate the outflow of capital, is likely to become vulnerable to sudden stops of capital 
inflows, hence, to balance of payments crises. A "sudden stops" crisis often entails a financial or currency crisis, accompanied by a sharp fall in output. ${ }^{3}$

The idea, put forth in the present paper is that a fixed exchange rate, or open capital markets, may be good, or may be bad, for macroeconomic performance, through multiple channels: the traditional trade channel and the financial crisis channel. Therefore, a fixed exchange rate regime may be bad if it generates a big increase in the probability of sudden stop crises, to a degree that dominates the positive effect through the direct channel; and vice versa.

A related policy-evaluation issue is dollarization, and its effect on the macroeconomic performance. The "original sin" concept, introduced by Barry Eichengreen and Ricardo Haussman (1999), explain the consequences for emerging markets of abrupt departures from an exchange rate peg regimes due to sudden stops in capital inflows. The "original sin" concept underpins a crucial vulnerability of the economy under peg regimes. The phrase refers to the inability of a country to borrow abroad in its own currency, because no foreign creditor is willing to gamble on the potential exchange rate instability. A plausible explanation for the widespread use in dollarized debt is that countries are forced into this position because their monetary and fiscal policies lack credibility. If a country issued debt in domestic currency, it would have an incentive to inflate its way out of debt. Investors, who expect that the government will succumb to such temptation, refuse to buy domestic

\footnotetext{
${ }^{3}$ For an early analytical approach to the problem of sudden stops, see Calvo (1998). Among recent papers on sudden-stops' vulnerability, and its relation to fixed exchange rate regimes, see also Calvo (2000), Calvo, Reinhart and Vegh (1995), Chang and Velasco (2000), Ghosh, Gulde and Wolf (2000), Obstfeld and Rogoff (1995) and Williamson (2000).
} 
currency-denominated debt papers. ${ }^{4}$ In net terms, the foreign currency liabilities of residents of developing and transition countries usually exceed their assets in foreign currencies, implying that they are exposed to exchange rate risk on their balance sheets, as well as through trade. Issues of both sovereign and corporate bonds on international markets are overwhelmingly in foreign currencies, even in the case of an advanced economy such as Korea, or a country whose exchange rate is strongly pegged to the U.S. dollar, such as Argentina in the 1990 s. $^{5}$

The organization of the paper is as follows. In section II we survey related empirical literature. In section III we provide a discussion of a background theoretical framework, which can serve as a guide to the empirical analysis. Section IV describes the econometric methodology. In section V we describe the data. Section VI reports on the main econometric findings concerning the role of the crisis probability in the evaluations of policy regimes. Section VII provides an empirical analysis of the dollarization channel. In section VIII we

\footnotetext{
${ }^{4}$ Indeed, ninety seven percent of all debt, placed in international markets between 1999 and 2001, was denominated in five currencies: the US dollar, the euro, the yen, the pound sterling and the Swiss franc. This feature of emerging markets' borrowing in the international market leads to balance-sheet type of currency crises, as formalized by Krugman (2000), and Schneider and Tornell (2000).

5 Part of this exchange rate risk can be hedged, although only (in the aggregate for a given developing country) to the limited extent that nonresidents are willing to hold local currency exposure. Large cross-holdings of foreign assets and liabilities means that the valuation channel of exchange rate adjustment has grown in importance, relative to the traditional trade balance channel. In this context, see also Lane and Milesi-Ferretti (2004), for an empirical analysis of the inter-connections between capital account openness and the exchange rate adjustment process.
} 
bring inflation crises into the empirical analysis; we also perform robustness tests, by using alternative classification of exchange rate regimes, and analyzing a sub-sample of the 100country sample. Section IX provides a diagrammatic exposition of the fundamental nonlinear effects of the exchange rate regimes, capital openness, and dollarization, based on the estimation. Finally, section X provides conclusions, caveats, and extensions.

\section{RELATED EMPIRICAL LITERATURE}

Strikingly, the empirical literature has not been able to identify clear-cut real effects of exchange-rate regimes on the open economy. Indeed, Marianne Baxter and Alan Stockman (1989) and Robert Flood and Andy Rose (1995) find that there are no significant differences in business cycles across exchange rate regimes. A recent study Frankel and Wei (2004) explores how output lost in crises is related to various controls, including the exchange rate flexibility, currency mismatch, FDI, etc. The exchange rate flexibility variable is not statistically significant. $^{6}$

\footnotetext{
${ }^{6}$ See however a recent study by Levy-Yeyati and Sturzenneger (2001), who find real effects of exchange-rate regime in cross-country data. Another exception is Rose (2000). In the paper, Rose uses evidence from existing currency unions in the world economy to estimate the effect of currency unions on international trade. Rose finds that a currency union (which is an extreme form of a peg) expands bilateral trade between two average member countries by a huge proportion (200\%, and more). Rose's currency union effects were reduced substantially when fixed country effects were incorporated in the analysis. Persson (2001) challenged Rose's analysis, but also finds a significant, albeit modest, effect of currency unions. Anderson and van Wincoop (2003) demonstrated the importance of including country fixed effects in gravity models. Although commonly estimated gravity equations generally have a very good fit to the data, they show that they are not theoretically grounded and prone to lead to biased estimation. They applied the method to solve the border puzzle.
} 
Similarly, no definitive view emerges as to the aggregate effects of capital account liberalization. Eichengreen (2001) who reviews the literature, points to ambiguities in the rather complex role played by capital account liberalization; and Rodrik (1998) finds no significant statistical association between capital account openness and growth. A recent study by Prasad et al (2005) finds that it is difficult to establish a robust causal relationship between the degree of financial integration and growth performance for developing countries. ${ }^{7}$

\section{THEORY AS A GUIDE TO EMPIRICAL ANALYSIS}

Paul Krugman (2000) proposes a stylized "sudden stops" model, based on the self-fulfilling expectation equilibrium (sun spots' equilibrium), to make sense of the number and nature of the emerging market crises of 1997-98. Credit is constrained by the borrower's net worth, whose value is indexed to the real exchange rate, because of dollarization. The real exchange

They find specifically that borders reduce bilateral national trade levels by plausible though substantial magnitudes.

${ }^{7}$ A more definite view concerning positives effects of capital account liberalization on output, which is advanced by Fischer (1998), is supported by some evidence, provided by Quinn (1997). The role of pre-existing policies, and of trade-account vs. capital-account sequencing, in determining the effects of capital control liberalization on growth and investment, is examined by Arteta, Eichengreen and Wyplosz (2001), Chinn and Ito (2002), and Tornell, Westermann, and Martinez (2004). A recent evaluation of this literature by Prasad et al. (2004) also yields inconclusive result. It shows no significant relationship between financial openness and growth in real per capita income across countries, even after controlling for a series of standard explanatory variables (initial income, initial schooling, investment-GDP ratio, political instability, and regional dummies. See also Ariyoshi et al (2000), Bhagwati (1998), Edwards (1999, 2000) and Kaplan and Rodrik (2000). 
rate and aggregate investment are jointly driven by exogenous aggregate volume of exports. The model is extended in Razin and Rubinstein (2004) to fit into a class of models with a unique equilibrium (i.e., with no sunspots). The extension builds on the recent global-games models (as in Morris and Shin (2000). The extended model posits an exogenous stochastic process for the fundamentals (e.g., aggregate export volumes) that foreign creditors estimate based on public and private information. The framework features a double guessing game by the foreign creditors, who receive noisy signals. First, each foreign creditor assesses the realized state of the domestic economy fundamentals; and, second, he/she guesses the likelihood of the credit extension-withdrawal action that all the other foreign creditors are going to take, given the signals they receive. A rational-expectations equilibrium of this global game is the set of self fulfilling guesses so that the level of domestic investment implicit in the credit offers must match the actual level of investment that takes place given those offers. Importantly, the equilibrium is summarized by a unique projected crisis probability, directly linked to the level of aggregate domestic investment. An essential feature of the equilibrium is the existence of some thresholds in the value of some synthetic index of fundamentals (e.g., aggregate export volumes) that separate "crisis states" from "no crisis states". Building on such global-games framework of crises implies that foreign creditors decide whether to keep lending to the country (be long on foreign currency) depending on whether their estimate of the fundamentals is above or below an endogenous equilibrium threshold. The position of the threshold depends: (a) on the distribution of the fundamentals; (b) on the stochastic features of the process through which information reaches foreign creditors; as well as (c) on the policy regime. See Box 1 for a formal description of the model of sudden stops. 
[BOX 1 ABOUT HERE]

\section{ECONOMETRIC METHODOLOGY}

The dependent variable is the GDP growth rate, as an indicator of macroeconomic performance. Policy-regime variables are modeled as dummy variables, capturing policyregime switches (whether a country switches from float to peg, or whether a country is imposing capital controls). We use lagged policy-regime dummies as instruments. The state of the economy is conceived as a continuous latent variable, capturing the strength of the exogenous fundamentals; and indicating the "crisis-prone states of nature". When this variable moves beyond a certain threshold, there is a "crisis-prone state". The latent variable is derived via a probit model, assessing the probability of having a crisis in the current year. The probit is specified using the same policy dummies as above, plus lagged sudden stops crises, government budget deficit, initial GDP per capita, etc. In Box 2 we describe the formal econometric model.

\section{[BOX 2 ABOUT HERE]}

The main goal of this methodology is to capture the non-linear effect of policy on macroeconomic outcomes, depending on the "crisis state" of the economy, as projected by market participants. ${ }^{8}$

\footnotetext{
${ }^{8}$ Nesting a probit estimate in a panel may raise in general issues in the distribution of the error. Often, a noisy explanatory variable may bias the standard errors in the second-stage growth regression. A bias in the standard errors exists when the latent variable, although being known to the economic agent, is, however unknown to the econometrician. This issue is mute in our case because the projected probability of the "crisis-prone state" is the same
} 


\section{Box 1: Theory as a Guide to the Empirical}

\section{Model}

There are $\mathrm{N}$ domestic entrepreneurs, who are single mindfully engaged in wealth accumulation, and $\mathrm{N}$ foreign creditors, who supply the credit necessary for domestic investment. Let $I_{t}^{a}$ denote investment in capacity by the individual entrepreneur, and the leverage is specified as $\lambda$ times the entrepreneur's net worth, W. Let $y_{t}, F_{t-1}$, and $p_{t}$, denote domestic output (produced by a CobbDouglas technology with a capital input income share $\alpha$ ), initial debt, indexed to foreign goods, and the relative price of foreign goods in terms of domestic goods (the real exchange rate), respectively.The foreign lender imposes a limit on the entrepreneur borrowings so that the investment, $I_{t}^{a}$, is constrained by

$I_{t}^{a} \leq(1+\lambda) W_{t}$

where, $W_{t}=\alpha y_{t}-p_{t} F_{t-1}$, is the entrepreneur's net worth.

The real exchange rate which clears the goods market is given by:

$p_{t}=\frac{[1-(1-\alpha)(1-v)] Y_{t}-(1-v) I_{t}}{\tilde{x}}$,

where, $\mathrm{I}=\mathrm{N} I^{a,}{ }_{Y}^{X_{t}}=N y$, denote the aggregate domestic investment and aggregate output, respectively; the coefficient $v$ denotes the marginal propensity

to import, and $X_{t}$ denotes the stochastic volume of exports, expressed in terms of foreign goods. Evidently, an increase aggregate investment spending triggers real appreciation through a "transfer problem" mechanism (see Krugman (2000). The foreign creditor will extend credit to its domestic entrepreneur's counterpart, if

$\left(1+\mathrm{r}_{t}\right) \frac{p_{t}}{p_{t+1}} \geq(1+r *)$

where, $\mathrm{r}$ and $\mathrm{r}^{*}$ denote the marginal productivity of capital and the foreign interest rate, respectively. Figure B.1 shows the equilibrium outcomes for three

values of exports, $X_{t}$, in the case of full public information. With high exports, the equilibrium investment is governed by the rate of return conditions. In the low export equilibrium, the entrepreneur is insolvent and the credit constraint is binding. Thus, investment is equal to zero. In the intermediate case there are multiple equilibrium investment outcomes, due to a expectations-coordination failure.

In the case of private information, a foreign creditor i receives a private signal $\theta_{i}$ regarding $\tilde{X}_{t} ; \theta_{i}=\tilde{X}_{t}+\varepsilon_{t i}$. The error term $\varepsilon_{t i}$ is assumed to be i.i.d. and uniformly distributed over $[-\varepsilon, \varepsilon]$. The foreign creditor's decision whether to extend credit to the domestic entrepreneur depends on her signal.

In the stochastic case, there exists a cut-off signal $\theta_{i}^{*}=X_{t}^{*}+\varepsilon_{t i}^{*}$, so that $\underset{N^{\sim} U[0,1]}{E}\left[\left(1+r_{t}\right) \frac{\tilde{p}_{\left(N_{t}^{*}, X_{t}^{*}\right)}}{p_{t+1}}\right]-(1+r *)=0$.

The marginal foreign creditor, who receives the threshold signal $\theta_{i}^{*}=X_{t}^{*}+$ $\varepsilon_{t i}^{*}$, must be indifferent between withholding, or extending the credit to the 


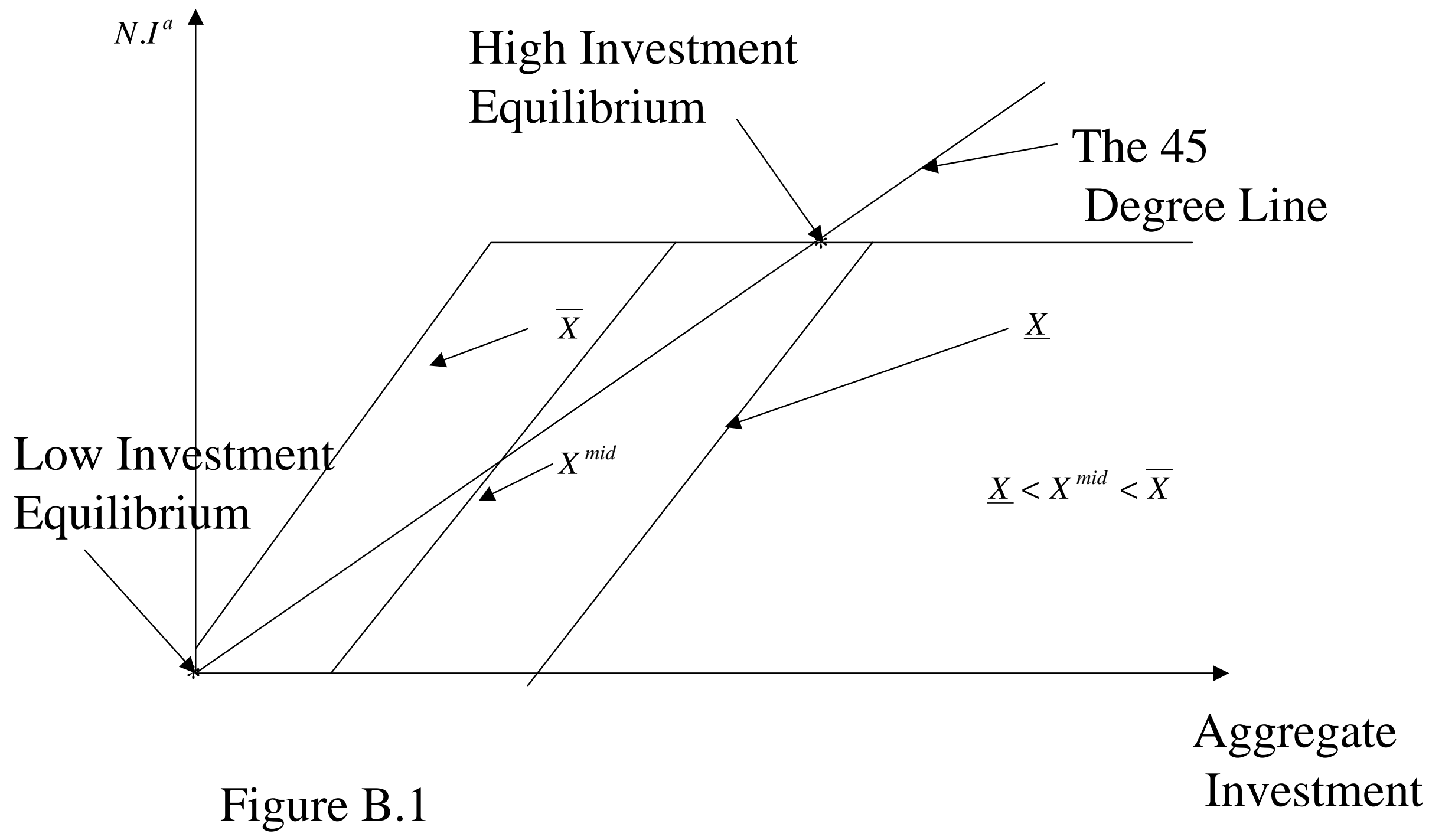


domestic entrepreneur counterpart. Observe that in the global game the equilibrium $\mathrm{p}_{t}$ is a decreasing function of the number of foreign creditors who decide to lend to the domestic entrepreneurs, $N$, and a decreasing function of the fundamental, in $X_{t}$.

The export threshold, $X_{t}^{*}$, determines uniquely the outcome of the global game. Below the threshold, investment is equal to zero because all foreign investors withold credit. Above the threshold, investment is driven by the unique rate-of-return consideration at a level $\bar{I}_{t}$, because all foreign investors extend credit. Ther is a unique probability of a sudden stop in capital flow, denoted by $\mathrm{G}(\mathrm{X}), G($.$) is an exogenous c.d.f. of export volumes:$

Prob $\left\{I_{t}=0\right\}=G\left(X_{t}^{*}\right)$.

The associated expected level of aggregate investment is given by

$(\bar{I})\left(1-G\left(X_{t}^{*}\right)\right)$.

\section{Box 2: The Statistical Model}

Let $Y_{1, j, t}$ and $Y_{2, j, t}^{*}$ denote the GDP per capita growth rate and a latent variable indicating the crisis prone state of the economy, for of country $j$ in time $t$, respectively. If $Y_{2, j, t}^{*} \geq 0$, a sudden stop crisis occurs, whereas if $Y_{2, j, t}^{*}<0$, the sudden stop crisis does not occur. The corresponding observable crisis variable is a binary variable, $Y_{2, j, t}$, which is equal to 1 if the sudden stop crisis occurs in a country $j$ at time $t$, and 0 otherwise.

$$
Y_{2, j, t}=\left\{\begin{array}{ll}
1 & \text { if } Y_{2, j, t}^{*} \geq 0 \\
0 & \text { otherwise }
\end{array} .\right.
$$

The indicators of the exchange rate and the liberalization regimes are dummy variables, $D_{1}$ and $D_{2}$ :

$$
D_{1, j, t}=\left\{\begin{array}{ll}
1 & \text { if peg } \\
0 & \text { if float }
\end{array},\right.
$$

and:

$$
D_{2, j, t}=\left\{\begin{array}{ll}
1 & \text { if capital controls } \\
0 & \text { if liberalization }
\end{array} .\right.
$$

The equation of the latent variable, $Y_{2, j, t}^{*}$, is a linear function of policy-regime dummies $\left(D_{1}, D_{2}\right)$ and a vector of controls $(Z)$ :

$$
Y_{2, j, t}^{*}=\beta_{2} Z_{j, t}+\gamma_{2} D_{1, j, t}+\delta_{2} D_{2, j, t}+\phi_{2} Y_{1, j, t}+\varepsilon_{2, j, t},
$$

where, $\varepsilon_{2, j, t}$ is a country specific time variant i.i.d. random shock.

The growth rate is a linear function of the policy regime indicators $\left(D_{1}, D_{2}\right)$, and a vector of standard controls $(X)$, as follows.

$$
Y_{1, j, t}=\beta_{1} X_{j, t}+\gamma_{1} D_{1, j, t}+\delta_{1} D_{2, j, t}+\phi_{1} \hat{Y}_{2, j, t}^{*}+\varepsilon_{1, j, t},
$$


where, $\varepsilon_{1, j, t}$ is a country specific time variant i.i.d. random shock and $\hat{Y}_{2, j, t}^{*}$ is the best predictor by the market participants of $Y_{2, j, t}^{*}$.

Typically by latent we mean that the variable is not observed by the economterician but is known to the market decision makers. This is not however the case here. Both the economterican and the market participants do not observe the "true" $Y_{2, j, t}^{*}$. They use a projection of $Y_{2, j, t}^{*}$ based on the right hand side of Equation (5). Accordingly, let $P_{j, t}=\operatorname{Pr}\left(Y_{2, j, t}=1 \mid \cdot\right)$ be the conditional probability that country $j$ will face a crisis in period $t$. That is,

$$
P_{j, t}=\operatorname{Pr}\left(\beta_{2} Z_{j, t}+\gamma_{2} D_{1, j, t}+\delta_{2} D_{2, j, t}+\phi_{2} Y_{1, j, t}>-\varepsilon_{2, j, t}\right) .
$$

Assume that $\varepsilon_{2, j, t} \sim N(0,1)$. Then, the equation for $P_{j, t}$ is given by

$$
P_{j, t}=\Phi\left(\beta_{2} Z_{j, t}+\gamma_{2} D_{1, j, t}+\delta_{2} D_{2, j, t}+\phi_{2} Y_{1, j, t}\right),
$$

where $\Phi$ is the cummulative distribution function of a unit normal distribution. The corresponding projected probability is given in the form of a Probit equation, as follows.

$$
\hat{P}_{j, t}=\Phi\left(\hat{\beta} Z_{j, t}+\hat{\gamma}_{2} D_{1, j, t}+\hat{\delta}_{2} D_{1, j, t}+\hat{\phi}_{2} Y_{1, j, t}\right)
$$

We use lag variables to instrument policy regime dummies, $D_{1, j, t-1}$ and $D_{2, j, t-1}$. To recover the parameters of interest in the growth equation we estimate the following equation.

$$
Y_{1, j, t}=\beta_{1} X_{j, t}+\gamma_{1} D_{1, j, t-1}+\delta_{1} D_{2, j, t-1}+\phi_{1} \Phi^{-1}\left(\hat{Y}_{2, j, t}^{*}\right)+\varepsilon_{1, j, t},
$$

Equation (9) provides consistent estimates for the parameters of interest for the economterican and the market participants. Note that the term $\Phi^{-1}\left(\hat{Y}_{2, j, t}^{*}\right)$ is the actual variable the market participants use in when making decisions.It is not the first- stage estimate by the econometrician of what market participant expectations. This is in contrast to the case where the market participants do observe the latent variable whereas the econometrician does not. In other words, the econometrician and the market participants share the same information set, and the latent variable is not an econometric proxy for the true variable. Therefore, in the 2nd stage of the regression analysis in our case, there is no need to correct for the estimates of the standard errors.

\subsection{The confounding effect of policy regimes}

What happens if one ignore the crisis probability variable in the growth equation?

Insuch a case, the estimated growth effects of the instrumented policy-regime dummies $D_{1, j, t}^{I V}, D_{1, j, t}^{I V}$ is given by: 
$E\left(\hat{\gamma}_{1}^{I V}\right)=\frac{\partial E\left(Y_{1, j, t} \mid X_{j, t}, D_{1, j, t}^{I V}, D_{2, j, t}^{I V}\right)}{\partial D_{1, j, t}}=\frac{1}{1-\phi_{1} \phi_{2}}\left(\gamma_{1}+\phi_{1} \frac{\partial \Phi^{-1}\left(\hat{P}_{j, t}\right)}{\partial D_{1, j, t}}\right)$

and:

$E\left(\hat{\delta}_{1}^{I V}\right)=\frac{\partial E\left(Y_{1, j, t} \mid X_{j, t}, D_{1, j, t}^{I V}, D_{2, j, t}^{I V}\right)}{\partial D_{2, j, t}}=\frac{1}{1-\phi_{1} \phi_{2}}\left(\delta_{1}+\phi_{1} \frac{\partial \Phi^{-1}\left(\hat{P}_{j, t}\right)}{\partial D_{2, j, t}}\right)$

Naturally, the crisis state has a negative net effect on growth:

$$
\phi_{1}<0, \phi_{1} \phi_{2}<1,
$$

Therfore, because the peg increases the crisis probability, and the imposition of capital controls lowers the crisis probability, we get:

$$
\begin{aligned}
& \frac{\partial \Phi^{-1}\left(\hat{P}_{j, t}\right)}{\partial D_{2, j, t}}>0 \\
& \frac{\partial \Phi^{-1}\left(\hat{P}_{j, t}\right)}{\partial D_{2, j, t}}<0 .
\end{aligned}
$$

Therefore, the IV estimate for the effect of exchange-rate regime on growth is equal to:

$$
\left(1-\phi_{1} \phi_{2}\right) E\left(\hat{\gamma}_{1}^{I V}\right)=\gamma_{1}+\phi_{1} \frac{\partial E\left(\Phi^{-1}\right)}{\partial D_{1, j, t}}<\gamma_{1}>0 .
$$

Similarly, the IV estimate for the effect of the imposition of capital controls on growth isequal to:

$$
\left(1-\phi_{1} \phi_{2}\right) E\left(\hat{\delta}_{1}^{I V}\right)=\delta_{1}+\phi_{1} \frac{\partial E\left(\Phi^{-1}\right)}{\partial D_{2, j, t}}>\delta_{1}<0 .
$$

Therefore, by ignoring the projected probability of sudden stops in the evaluation of the effect of the peg and the imposition of capital controls, the econometrician understates the direct effects of these regime switches. In other words, the estimators of the effect of the peg and the imposition capital controls are biased toward zero.

Note also that the $\partial E\left(\Phi^{-1}\right) / \partial D_{1, j, t}$ and $\partial E\left(\Phi^{-1}\right) / \partial D_{1, j, t}$ are the sample average effects of policy regimes on the crisis probability. But the $\Phi^{-1}$ function, under the assumption of the normal distribution is non linear. Therefore, $\frac{\partial E\left(\Phi^{-1}\right)}{\partial D_{2, j, t}}>\frac{\partial\left(\Phi^{-1}\right)}{\partial D_{2, j, t}}$ for countries with strong fundamentals, and $\frac{\partial E\left(\Phi^{-1}\right)}{\partial D_{2, j, t}}<$ $\frac{\partial\left(\Phi^{-1}\right)}{\partial D_{2, j, t}}$ for country with weak fundamentals. 


\section{DATA}

Our data set consists of 100 low-and middle-income countries (43 African countries, 26

Asian countries, 26 countries from Latin America and the Caribbean, and 5 European countries). The list of countries is shown in Table 1. The main source of data is the World Bank (World Development Indicators and Global Development Finance). The annual data ranges from 1971 to $2002 .{ }^{9}$ We implement a binary index based on multiple categories of the IMF classification of exchange rate regimes, for the broad sample with the 100 countries. We also implement a binary index based on the different multiple categories of the Reinhart and Rogoff classification of exchange rate regimes, but only for a sub-sample of 58 countries of the 100 countries. ${ }^{10}$ Capital-account openness is also measured as a binary index based of restrictions on capital account transactions, reported in the IMF Annual Report on Exchange Arrangements and Exchange Restrictions. ${ }^{11}$

for market participants and the econometrician. Hence, in our case the second-stage standard errors are not biased.

${ }^{9}$ We updated the data set, originally assembled by Gian Maria Milesi-Ferretti and Assaf Razin (2000), to account for the Asian crisis in 1997.

${ }^{10}$ Reinhart and Rogoff (2004) updated the IMF official classification of exchange rate regimes prior to 1997, as described in the various issues of the IMF's Exchange Arrangements and Exchange Restrictions. The IMF empirical definition of exchange rate regimes is based on formal government statements. The Reinhart-Rogoff classification is based on an empirical algorithm, factoring in ex-post behavior. Both are not pure rule-based proxies.

11 These are rule-based, but not quantitative measures. For alternative measures, see also Edison et al (2004). 
We measure sudden stops' crises by a large annual depreciation in the real exchange rate. In doing so we attempt to capture the effects of the crisis on the real side of the economy. ${ }^{12} 13$ Evidently, unexpected fluctuations in the real exchange rate (rather than the nominal exchange rate) are more likely to have significant balance-sheet effects and other real side effects. Concretely, the sudden-stops crisis is defined by sharp changes of the real exchange rate, with a 15 percent-per-year threshold (one standard deviation in our sample).

Table 1 provides a list of countries in our broad sample. Table 2 describes the frequency of sudden-stops crises, exchange-rate regimes, and capital-account policy switches in the broad sample. Overall, about 22 percent of the observations are associated with sudden-stops crises; an average of 1 percent to 4 percent of the observations indicate a float-to-peg, peg-to-float, switches to capital-controls, or switches to liberalization.

\footnotetext{
12 Typically in the currency crisis literature sudden stops are measured by free falls in the nominal exchange rate. However, this does not distinguish between domestic price crises and balance-of-payments crises. In our indicator, crisis episodes do not include, therefore, countries which suffer from bouts of high inflation and currency depreciation, but with a relatively stable real exchange rate, because they do not qualify to be classified as balanceof-payments crises. Evidently, the real exchange rate measure for crisis is strongly correlated with sharp reversals in the current-account balance. See Milesi-Ferretti and Razin (2000). See also Calvo, Izquierdo and Majia (2004) on sudden stops and real exchange rate fluctuations.

${ }^{13}$ Calvo, Izquierdo, and Mejia (2004) find that real exchange rate fluctuations coming hand in hand with sudden stops are a unique phenomenon in emerging-market economies. They use a sample of 32 developing countries, to analyze the empirical characteristics of sudden stops in capital flows and their relations to balance sheet effects. See also Bacchetta, Aghion and Banerjee (2001), Krugman (2000), Allen, Rosenberg, Keller, Sester, and Roubini (2002), and Eichengreen and Hausmann (1999).
} 


\section{MAIN EMPIRICAL FINDINGS}

We begin by reporting on the estimated effects of a regime switch. We start with the effects of policy-regime switch, float to peg, peg to float, liberalization to capital controls, and capital controls to liberalization. We do so, with, and without country fixed effects. To underscore the role of the probability of sudden stops, we estimate each specification twice; that is, including and excluding the probability of a crisis. We report our findings in Table 3.

In the benchmark case where the crisis probability is absent from the growth equation, we find negligible effects of peg and liberalization policy dummies on growth, with and without fixed country effects; as expected from the traditional literature.

\section{(i) Policy-Regime Determinants of Growth}

Controlling for the crisis probability in the growth equation, in column (I) and (iii) of Table

3 , the coefficients of the policy dummies are significant in the growth equation, with and without fixed country effects. The coefficient of the crisis probability in the growth equation is negative: barely significant without country fixed effects, but highly significant with country fixed effects.

(ii) Policy-Regime Determinants of the Probability of Crisis

In the lower panel of Table 3 one can see that the probability of crises increases with a switch to peg, and falls with the imposition of capital controls, by about the same order of 
magnitude (almost 30 percent). Note that the coefficients of the policy dummies in the probit equation are highly significant, both with and without country fixed effects.

\section{(iii) Reduced-Form Marginal Effect of a Switch in the Policy Regime}

Observe that both the reduced-form marginal effect of a switch to peg, and the imposition of capital controls, is small. ${ }^{14}$ This is evidently consistent with the small coefficient of the policy dummy in the benchmark growth equation. This is also a typical finding in the traditional literature. In our case, however, the statement applies only to the sample average. Because the probit equation is non-linear and the growth equation is linear, for any countryspecific and time specific cases, one effect may strictly dominate the other, or vice versa. The non-linearity is illustrated in section IX.

We now address some potential econometric issues.

Is there a self-selection issue? When the crisis probability is very high, a successful switch to peg can only be implemented by countries for which governments have some strong belief about the health of domestic economic fundamentals (like the case of Hong Kong during the Asian crises). Thus, the conclusion that a switch to peg is good for growth in state of very high probability of crisis may not be valid because it may be based on a self-selection of countries, from a pool of countries, where the same crisis probability presumably corresponds to different fundamentals. This self-selection problem does not, however, arise

\footnotetext{
14 The reduced-form marginal effect is calculated as follows. The coefficient of a policy dummy in the probit is multiplied by the coefficient of the crisis probability in the growth equation. The product is in turn added to the coefficient of the corresponding policy dummy in the growth equation.
} 
in our case, because we control for country fixed effects. The country fixed effects effectively capture the main characteristics of the health of the country domestic economic fundamentals.

Is there an endogeneity issue, concerning the crisis probability in the growth equation? The dependency of the growth rate on crisis probability originates in effect from the country characteristics, which again are captured by the exogenous country fixed effects. That is, the country fixed characteristics trigger slow growth or fast growth. At the same time they could either increase, or reduce the crisis probability. Because country-fixed effects are exogenous, the coefficient estimate of the crisis probability in the growth equation remains unbiased.

Table 4 provides some first-look results concerning the persistence of the effect of policy regimes on macroeconomic performance. ${ }^{15}$ We distinguish between the effects of regime switch dummies and regime level dummies. This somewhat static methodology aims at capturing persistent and transitory effects of policy regimes, in a sample which does not have time series of other policy variables that enable full-fledged dynamic analysis. The main findings are:

(i) Determinants of the Projected Crisis Probability

The coefficient estimates of policy regime switches, but not of the policy regime levels, are found to be significant in the probit equation. This means that the crisis probability is

\footnotetext{
${ }^{15}$ Full-fledged dynamic analysis is not undertaken because the country characteristics do not have considerable time-variation in the data.
} 
sensitive to changes in policy regimes but not sensitive to whether the country is under peg or float, or whether the capital account is open or not.

(ii) Determinants of GDP Growth

Controlling for the crisis probability in the growth equation, the coefficient estimates of both types of the policy regime switch, as well as the two types of the policy regime level are significant in the growth equation; albeit only in the case where country fixed effects are excluded. Once we control for country fixed effects, only the coefficient estimates of the policy regime switch are significant in the growth equation. The Durbin-Watson measure of serial correlation in our regression analysis does not significantly deviate from 2 , strengthening the evidence of no level effect.

Thus, it is fair to conclude that in the broad sample of 100 countries, using the IMF classification of exchange rate regimes, we do not have good evidence for persistent effects of the policy dummies on growth.

\section{Dollarization and Sudden Stops}

Different economies in our sample also have different levels of exposure to capital flow volatility that can trigger unanticipated fluctuations in the real exchange rate. ${ }^{16}$ We use the

\footnotetext{
16 The link between dollarization and exchange rate regimes is driven by several alternative mechanisms. Reinhart, Rogoff and Savastano (2004) find that dollarization appears to
} 
ratio of the country's foreign currency liabilities to its money supply (FLM), as a proxy for the country's foreign currency exposure to fluctuations in the real exchange rate. We address the effect of policy-regime switch on dollarization, and the role of dollarization in the macroeconomic process.

Table 6 provides estimates of the influence of policy-regime switch on dollarization. Column (i) indicates that the policy regimes (a switch to peg, and the imposition of capital controls) do not have a direct effect on dollarization. Column (ii) indicates a significant effect of the crisis probability, as a single explanatory variable, on dollarization. Column (iii) indicates that policy regimes do not directly affect dollarization, but only indirectly through the crisis probability. The latter significantly explain the dollarization. With regard to the indirect influence of policy regimes on dollarization through the effect of the regimes on the crisis probability, recall that in Table 3 we demonstrate that a switch to a peg raises and the imposition of capital controls reduces the probability.

We now turn to the analysis of how dollarization influences growth. Column (i) and (ii) of Table 7 indicate that FLM, the dollarization measure, does not have any direct influence on increase exchange rate pass-through. This mechanism may reinforce the claim that the "fear of floating" is a greater problem for developing economies, with highly dollarized debt. The role of balance sheet effects, the linkage between currency risk and country risk, and the impact of dollarization on trade are analyzed in Levy Yeyati and Sturzenegger (2003). See also Calvo and Reinhart (2000). 
growth, once we control for the actual realization of sudden stops' crisis. The crisis, as expected, reduces growth, and in a significant way. In column (iii) of Table 7 we introduce the interaction between dollarization and the realized sudden stops. The coefficient of the interaction term is negative and highly significant. This means that, although dollarization does not have an independent influence on growth, the interaction between dollarization and the actual crisis, tend to reduce the growth rate drastically.

This means that the following policy-regime induced mechanism may have been at work in the sample. The imposition of capital controls tend to lower the probability of sudden stops; and the decrease in the probability of sudden stops, in turn, tend to raise the level of dollarization. If a crisis actually occurs, then the growth rate diminishes. If, however the crisis does not materialize, then growth is unaffected.

\section{Inflation Crises and Robustness Tests}

The literature has been dealing extensively with the relation between inflation and growth. Bruno and Easterly (1998) assume that inflation has substantial adverse effects on the economy only beyond a certain threshold. They find that growth falls sharply during discrete high inflation crises; then growth recovers quickly after inflation falls below the threshold. The Bruno-Easterly methodology is based on the actual realization of inflation crises. Our methodology points out to the role of a latent "crisis-prone state", estimated by a continuous crisis probability function. This means the even if the crisis does not materialize, the crisis probability could be sufficiently big to affect the rate of growth. In this section we consider the effect of domestic price crises in addition to sudden stops' crises. 
With regard to exchange rate regimes, we switch, in this section, to the Reinhart-Rogoff classification. The alternative classification applies to only a subset of the original sample of 100 countries. Accordingly, in this section we perform a variety of robustness tests: samplerobustness, and regression-specification. Table 8 describes the frequency of currency and price crises in the sub-sample. Sudden stops' episodes appear in 65.5 percent of observations, whereas domestic-price-crisis episodes occur in 46.1 percent of the observations. Table 9 describes the frequency of switches to peg, and switches to float in the sub-sample. Both types of policy-regime switch occur in about 10 percent of the total of the sub-sample observations.

Column (i) in Table 10 (using the Reinhart-Rogoff classification in the sub-sample), is analogous to column (iv) in Table 3 (using the IMF classification in the broad sample of 100 countries). Qualitatively, the findings are similar: a switch to peg has a positive coefficient, a switch to capital controls has a negative coefficient, and the crisis probability has a negative coefficient; all estimators are statistically significant. This serves as evidence for the robustness of our methodological approach.

In column (ii) of Table 10 the sudden stops' probability includes the effect of the domestic price crisis. Notice that the effect of the crisis probability on growth is barely significant. In column (iii) we include two types of a projected probability of sudden stops: one which includes, and the other which excludes, the effect of the price crisis. Observe that the coefficient of the latter type of projected probability is highly significant and negative. The 
estimated coefficient is larger in absolute value than the corresponding coefficient in column (i), Table 10. The coefficient of projected probability of sudden stops which includes the effect of price crisis, in column (iii), is however not significant. We interpret this as evidence that a domestic price crisis affects growth through the sudden-stops probability channel.

\section{FUNDAMENTAL NON-LINEARITIES}

Recall that to find any systematic difference in the macroeconomic process across exchange rate regimes, the analysis has to account for non-linearities in the effect of balance-ofpayments policy regimes on growth.

The reduced-form marginal effect of a policy-regime switch from float to peg, which incorporates both direct and an indirect effects (which is working through the crisis probability), is plotted as a U-shaped graph in Figures 1, against the projected probability. In the two extreme ranges (when the probability is relatively low and relatively high) the marginal effect of the policy switch is positive. In this the regime switch does not trigger a big change in the probability, and the direct effect on growth of the regime switch dominates the indirect effect. In the intermediate range for the probability function, the reduced-form marginal effect of a policy-regime switch from float to peg is negative because the policyregime switch does not generate a big marginal increase in the probability, and the indirect effect of the regime switch dominates the direct effect. Similarly, Figure 2 demonstrates how the reduced-form marginal effect of a switch from capital controls to capital-account liberalization, which incorporates both the direct and the indirect effects, depends on the 
crisis probability. The U-shaped diagram implies that the marginal effect of the policy switch is positive, in the extreme ranges of the projected probability function. In contrast, in the intermediate range the marginal effect of the policy-regime is negative because the crisis probability is very sensitive to the policy-regime switch. Figure 3 plots the reduced-form marginal growth effect of the regime switch to peg against the probability of sudden stops; with and without the imposition of capital controls. Notice capital controls transformed the U-shaped curve to a downward sloping curve, except for small values of the crisis probability. Figure 4 plots the reduced-form marginal growth effect of the switch to peg, against the crisis probability, for two levels of dollarization $(\mathrm{FLM}=0.75$ and FLM $=0.1$ ). With smaller dollarization, the U-shaped curve is flatter than with large dollariztion, indicating the dampening effect of dollarization on the probability of crisis.

\section{CONCLUSION AND EXTENSIONS}

Our estimation implies that the overall effect of balance-of-payments regimes on macroeconomic performance works through the direct channel and the crisis probability channel. The latter is intrinsically non-linear. There are ranges for the set of the main explanatory variables, for which the effect of the policy regime on the likelihood of a crisis is substantial, whereas in other ranges the effect is unimportant. The reduced-form marginal effect of a policy-regime switch don growth depends on the magnitude of the probability of sudden stops crisis, and on the degree of dollarization. This means the exogenous countryspecific shocks in the sample period imply that policy-makers faced different choices with regard to the desired exchange rate, and capital-account liberalization, regimes. 
We list a few caveats.

The data have little time variation concerning the country-specific fiscal and monetary policies, which does not enable a full-fledged dynamic analysis. Accordingly, the econometric methodology is effectively static.

The background theory posits that optimizing agents will design their portfolio strategies based on expectations about policy rules. It is not necessary that a switch from float to peg has the same meaning in different policy and institutional environments. On the other hand, policy rules may be endogenous in an environment vulnerable to sudden stops.

To take care of the issue of the endogeneity of policy regimes we had to resort to lagged policy regime dummies, as instruments.

Indicators of capital controls used in the analysis do not distinguish between controls on inflows and outflows. These two types of controls may have quite different effects on capital inflows, and therefore on the probability of sudden stops.

The IMF empirical definition of exchange rate regimes is based on formal government statements. The Reinhart-Rogoff classification is based on an empirical algorithm, clustering ex-post behavior. Both are not pure rule-based proxies, as our framework assumes.

We discuss two extensions.

It has been a well-discussed view that openness to trade makes countries less vulnerable to sudden stops. Rose (2002) argues that the threatened penalty of lost trade is the answer to the puzzle "why do countries seldom default on their international debt?". He offers empirical evidence that strong trade links are correlated with low default probabilities. But strong trade links are expected also to correlate with growth rates. Thus trade openness may have two reinforcing effects on growth: a direct effect on the growth process, and an indirect effect on 
growth through the probability of sudden stops. A useful extension is to apply our methodology also to international - trade regimes.

Another extension is to consider also the choice between monetary policy rules. Different rules influence the probability of bank runs (as in Diamond and Diving (1983)), and the probability of stock market crashes, in different ways. Proper evaluation of monetary rules (exchange rate target, monetary aggregates target, or interest target) can internalize the effect of these rules on the probability of financial crises; similar to our analysis of the evaluation of balance of payments regimes.

\section{References}

Allen, Mark, Christopher Rosenberg, Christian Keller, Brad Sester, and Nouriel Roubini, (2002). "A Balance Sheet Approach to Financial Crisis," IMF WP/02/210 (Washington: International Monetary Fund).

Anderson, James, and Eric van Wincoop (2003). "Gravity with Gravitas: A Solution to the Border Puzzle," American Economic Review, Vol. 93, pp. 170-92.

Ariyoshi, Akira, Karl Habermeier, Bernard Laurens, Incintker-Robe, Jorge Ivan CanalesKriljenko, and Andrei Kirilenko (2000). "Capital Controls: Country Experiences with Their Use and Liberalization,” Occasional Paper 190 (Washington: International Monetary Fund).

Arteta, Carlos, Barry Eichengreen, and Charles Wyplosz, (2001), "When Does Capital Account Liberalization Help More than it Hurts?" NBER Working Paper No. 8414 (Cambridge, Massachusetts, National Bureau of Economic Research).

Bacchetta, Philippe, Philippe Aghion, and A. Banerjee (2001). "Currency Crises and Money, in Credit-Constrained Economies," European Economic Review, Vol. 45, pp. 11211150 .

Basu, Kaushik (2003). "Globalization and the Politics of International Finance: The Stiglitz Verdict," Journal of Economic Literature, Vol. XLI, pp. 885-899. 
Baxter, Marianne, and Alan Stockman (1989), "Business Cycle and Exchange Regime: Some International Evidence," Journal of Monetary Economics, Vol. 23, pp. 377-400)

Bhagwati, Jagdish (1998). "The Capital Myth," Foreign Affairs, Vol. 77, No. 3, pp. 7-12.

Bruno, Michael, and William Easterly, 1998, "Inflation Crises and Long-run Growth," Journal of Monetary Economics, Vol. 41, pp. 3-26.

Calvo, Guillermo A. (1998). "Capital Flows and Capital-Market Crises: The Simple Analytics of Sudden Stops," Journal of Applied Economics (CEMA), Vol. 1(1), pp. $35-54$.

Calvo, Guillermo A. (2001). "Capital Markets and the Exchange Rate, With Special Reference to the Dollarization Debate in Latin America," mimeo, University of Maryland, (April).

Calvo, Guillermo A., Alejandro Izquierdo, and Luis-Fernando Mejia (2004). "On the Empirics of Sudden Stops: The Relevance of Balance-Sheet Effects," mimeo, University of Maryland (May).

Calvo, Guillermo A., and Carmen M. Reinhart (2000). "Reflections on Dollarization," in Alberto Alesina and Robert Barro (editors), Currency Unions, forthcoming. (Stanford: Hoover Institution Press).

Calvo, Guillermo A., and Carmen M. Reinhart (2002). "Fear of Floating," The Quarterly Journal of Economics, Volume CXVII, No. 2, pp. 379-408.

Calvo, Guillermo A., Carmen M. Reinhart, and Carlos A. Vegh (1995). "Targeting the Real Exchange Rate: Theory and Evidence," Journal of Development Economics, Vol. 47, pp. 97-133.

Calvo, Guillermo A.,and Carlos Vegh (1999). "Inflation Stabilization and BOP Crises in Developing Countries," NBER Working Paper 6925 (Cambridge, Massachusetts: National Bureau of Economic Research.

Chang, Roberto and Andres Velasco (2000). "Exchange Rate Policy for Developing Countries," American Economic Review, Papers and Proceedings, Vol. 90, No. 2 , pp. 71-75.

Chinn, Menzie D., and Hiro Ito (2002). "Capital Account Liberalization, Institutions and Financial Development: Cross- Country Evidence," NBER Working Paper No. 8967 (Cambridge, Massachusetts: National Bureau of Economic Research).

Diamond D., and P. Dybvig (1983). "Bank Runs, Deposit Insurance and Liquidity," Journal of Political Economy, Vol. 91, pp. 401-419. 
Edison, Hali, Michael Klein, Luca A. Ricci, and Torsten M. Slok (2004). "Capital Account Liberalization and Economic Performance: Survey and Synthesis, IMF Staff Papers, Vol. 51, No. 2 , pp. 219- 256.

Edwards, Sebastian (1999). "How Effective are Capital Controls?" Journal of Economic Perspectives, Vol. 13, No 4 (Fall), pp. 65-84.

Edwards, Sebastian (2000). "Exchange Rate Regimes, Capital Flows and Crisis Prevention," NBER (December). Cambridge, Massachusetts: National Bureau of Economic Research.

Eichengreen, Barry, 2001. "Capital-Account Liberalization: What Cross-Country Studies Tel Us?" World Bank Economic Review, Vol. 15, pp. 341-365 (Washington: The World Bank).

Eichengreen, Barry, and Ricardo Hausmann (1999). "Exchange Rates and Financial Fragility," NBER Working Paper 7418 (November). Cambridge, Massachusetts: National Bureau of Economic Research.

Fischer, Stanley (1998). "Capital-Account Liberalization and the Role of the IMF," in Should the IMF Pursue Capital-Account Convertibility? Princeton Essays in International Finance, Vol. 207, pp. 1-10, Princeton University, International Finance Section,

Fischer, Stanley (2001) "Distinguished Lecture on Economics in Government-Exchange Rate Regimes: Is the Bipolar View Correct?" The Journal of Economic Perspectives, Volume 15, No. 2 (spring), pp. 3-24.

Flood, Robert P., and Andy Rose (1995). "Fixing Exchange Rates: A Virtual Quest for Fundamentals," Journal of Monetary Economics.

Frankel, Jeffrey A., and Shang-Jin Wei (2004). "Managing Macroeconomic Crises," NBER Working Paper No. 10907 (November). Cambridge, Massachusetts: National Bureau of Economic Research.

Ghosh, Atish R., Anne-Marie Gulde, and Holger C. Wolf (2000). "Currency Boards: More than a Quick Fix?" Economic Policy, Vol. 31, pp. 270-335.

International Monetary Fund, Annual Report on Exchange Arrangements and Exchange Restrictions, various years.

Kaplan, Ethan and Dani Rodrik (2000). "Did the Malaysian Capital Controls Work?" Kennedy School of Government (December). 
Krugman, Paul (2000). "Balance Sheets, The Transfer Problem, and Financial Crises," in International Finance and Financial Crises: Essays in Honor of Robert P. Flood, $J r$. , ed. by Peter Isard, Assaf Razin, and Andrew K. Rose, pp. 31-44 (Kluwer Academic Publishers).

Lane, Philip R., and Gian Maria Milesi-Ferretti (2004). "Financial Globalization and Exchange Rates," CEPR Discussion Paper No. 4745 (November).

Levy-Yeyati, Eduardo, and Federico Sturzenegger, eds., (2000). A Primer on Dollarization: Debates and Policy Alternatives, MIT Press.

Levy- Yeyati, Eduardo, and Federico Sturzenegger (2001). "Exchange Rate Regimes and Economic Performance," IMF Staff Papers, Vol. 47, pp.62-98.

Milesi-Ferretti, Gian Maria, and Assaf Razin (2000). in Currency Crises, ed. by Paul Krugman (Chicago: University of Chicago Press).

Morris, Stephen, and Hyun Song Shin (2000). "Rethinking Multiple Equilibria in Macroeconomic Modeling," NBER Macroeconomics Annual, Number 15, pp. 139-161.

Milesi-Ferretti, Gian Maria, and Assaf Razin (2000). "Current Account Reversals and Currency Crises: Empirical Regularities," in Currency Crises, ed. by Paul Krugman, pp. 285-323 (Chicago: University of Chicago Press).

Obstfeld, Maurice and Kenneth Rogoff (1995). "The Mirage of Fixed Exchange Rates," Journal of Economic Perspectives, Vol. 9, No. 4, pp. 73-96.

Quinn, Dennis (1997). "The Correlates of Change in International Financial Regulation," American Political Science Review, Vol. 91, No. 3, pp.531-51.

Persson, Torsten (2001). "Currency Unions and Trade: How Large is the Treatment Effect?" Economic Policy, Vol. 33, pp. 433-448.

Prasad, Eswar, Rogoff, Kenneth, Wei, Shang-Jin, and Kose, M. Ayhan (2005). " Financial Globalization, Growth on Developing Countries, and Volatility in Developing Countries" NBER Working Paper no. 10942, forthcoming in Globalization and Poverty, Ann Harrison (editor), University of Chicago Press.

Razin, Assaf, and Yona Rubinstein (2004). "Growth Effects of the Exchange-Rate Regime and the Capital-Account Openness in A Crises-Prone World Market: A Nuanced View" (Tel Aviv University). 
Reinhart, Carmen, and Ken Rogoff (2004). "The Modern History of Exchange Rate Arrangements: A Reinterpretation," Quarterly Journal of Economics, Vol. 119, Issue 1, pp. 1-48.

Reinhart, Carmen, Ken Rogoff and Miguel Savastano (2004). NBER Working Paper No. 10015, forthcoming in the Quarterly Journal of Economics.

Rodrik, Dani (1998). "Who Needs Capital-Account Convertibility?" Princeton Essays in International Finance, No. 207, pp. 55-65.

Rose, Andrew (2000). "One Money, One Market: Estimating the Effect of Common Currencies on Trade," Economic Policy, Issue 30, pp. 7-45.

Rose, Andrew (2002). “A Reason Why Countries Pay Their Debts: Renegotiation and International Trade," NBER Working Paper No. 8853.

Schneider, Martin , and A. Tornell (2000,). "Balance Sheet Effects, Bailout Guarantees and Financial Crises," NBER Working Paper No. W8060.

Tornell, Aaron, Frank Westermann, and Lorenza Martinez (2004). "The Positive Link Between Financial Liberalization, Growth, and Crises," NBER Working Paper No. 10293 (February).

Williamson, John (2000). "Exchange Rate Regimes for Emerging Markets: Reviving the Intermediate Option". (Washington: Institute for International Economics (September). 
Table 1:

The Frequency of Crises, Switches Between Float and Peg and Switches between Capital Controls and Liberalizations (\%)

Variable

Frequency

Crsises

22.61

Switches to peg

1.71

Switches to float

3.91

Switches to controls

1.03

Switches to liberalizations

0.9 
Table 2:

List of Countries

\begin{tabular}{|c|c|c|c|}
\hline (1) & Algeria & (51) & Malawi \\
\hline (2) & Argentina & (52) & Malaysia \\
\hline (3) & Bangladesh & (53) & Maldives \\
\hline (4) & Barbados & (54) & Mali \\
\hline (5) & Belize & (55) & Malta \\
\hline (6) & Benin & (56) & Mauritania \\
\hline (7) & Bhutan & (57) & Mauritius \\
\hline (8) & Bolivia & (58) & Mexico \\
\hline (9) & Botswana & (59) & Morocco \\
\hline (10) & Brazil & (60) & Myanmar \\
\hline (11) & Burkina Faso & (61) & Nepal \\
\hline (12) & Burundi & (62) & Nicaragua \\
\hline (13) & Cameroon & (63) & Niger \\
\hline (14) & Cape Verde & (64) & Nigeria \\
\hline (15) & Central African & (65) & Oman \\
\hline (16) & Chad & (66) & Pakistan \\
\hline (17) & Chile & (67) & Panama \\
\hline (18) & China & (68) & Papua New Guinea \\
\hline (19) & Colombia & (69) & Paraguay \\
\hline (20) & Comoros & (70) & Peru \\
\hline (21) & Congo & (71) & Philippines \\
\hline (22) & Cote d'Ivoire & (72) & Portugal \\
\hline (23) & Dominican Rep. & (73) & Romania \\
\hline (24) & Ecuador & (74) & Rwanda \\
\hline (25) & Egypt, Arab Rep & (75) & Sao Tome and $\mathrm{Pr}$ \\
\hline (26) & El Salvador & (76) & Senegal \\
\hline (27) & Equatorial Guin & (77) & Seychelles \\
\hline (28) & Ethiopia & (78) & Sierra Leone \\
\hline (29) & Fiji & (79) & Solomon Islands \\
\hline (30) & Gabon & (80) & Somalia \\
\hline (31) & Gambia, The & (81) & South Africa \\
\hline (32) & Ghana & (82) & Sri Lanka \\
\hline (33) & Grenada & (83) & St. Vincent \\
\hline (34) & Guatemala & (84) & Sudan \\
\hline (35) & Guinea & (85) & Swaziland \\
\hline (36) & Guinea-Bissau & (86) & Syrian Arab Rep \\
\hline (37) & Guyana & (87) & Tanzania \\
\hline (38) & Haiti & (88) & Thailand \\
\hline (39) & Honduras & (89) & Togo \\
\hline (40) & Hungary & (90) & Trinidad and To \\
\hline (41) & India & (91) & Tunisia \\
\hline (42) & Indonesia & (92) & Turkey \\
\hline (43) & Iran, Islamic R & (93) & Uganda \\
\hline (44) & Jamaica & (94) & Uruguay \\
\hline (45) & Jordan & (95) & Vanuatu \\
\hline (46) & Kenya & (96) & Venezuela \\
\hline (47) & Lao PDR & (97) & Western Samoa \\
\hline (48) & Lesotho & (98) & Zaire \\
\hline (49) & Liberia & (99) & Zambia \\
\hline (50) & Madagascar & (100) & Zimbabwe \\
\hline
\end{tabular}


Table 3:

Exchange Regime and Capital Controls: Cyclical Effects

\section{Panel A: Dependent Variable: Growth Rates}

Variables

Switching to peg between $\mathrm{t}-2$ to $\mathrm{t}-1$

Switching to float between t-2 to t-1

Switching to Capital Controls between t-2 to t-1

The probability of having currency crisis this year ${ }^{\wedge}$

\section{Controllers}

1970 GDP per capita

Currency crisis at time t-1

Currency crisis at time t-2

Growth rate at time t-1

Growth rate at time t-2

\begin{tabular}{|c|c|c|c|}
\hline $\begin{array}{l}\text { OLS } \\
\text { (i) }\end{array}$ & $\begin{array}{l}\text { OLS } \\
\text { (ii) }\end{array}$ & $\begin{array}{l}\text { FE } \\
\text { (iii) }\end{array}$ & $\begin{array}{ll}\text { FE } & \\
& \text { (iv) } \\
\end{array}$ \\
\hline $\begin{array}{l}1.6423 \\
(0.7503)^{\star}\end{array}$ & $\begin{array}{l}4.6209 \\
(1.4795)^{\star *}\end{array}$ & $\begin{array}{l}1.2041 \\
(0.9958)\end{array}$ & $\begin{array}{l}5.0215 \\
(1.7630)^{\star *}\end{array}$ \\
\hline $\begin{array}{l}0.1761 \\
(0.6483)\end{array}$ & $\begin{array}{l}0.6383 \\
(0.6692)\end{array}$ & $\begin{array}{l}-0.0539 \\
(0.7039)\end{array}$ & $\begin{array}{l}0.2005 \\
(0.7401)\end{array}$ \\
\hline \multirow[t]{2}{*}{$\begin{array}{l}-1.8832 \\
(0.8616)^{\star}\end{array}$} & $\begin{array}{l}-4.7173 \\
(1.5363)^{\star *}\end{array}$ & $\begin{array}{l}-1.9592 \\
(1.0495)\end{array}$ & $\begin{array}{l}-6.3843 \\
(2.0713)^{\star *}\end{array}$ \\
\hline & $\begin{array}{l}-9.6164 \\
(5.0663)\end{array}$ & & $\begin{array}{l}-12.7791 \\
(4.9934)^{\star}\end{array}$ \\
\hline
\end{tabular}

$\begin{array}{ll}-0.0012 & -0.0011 \\ (0.0005)^{\star} & (0.0005)^{\star}\end{array}$

0.5612

(0.5949)

2.7602

$(1.2740)^{*}$

0.7579

(0.4506)

2.5482

$(0.8331)^{\star \star}$

-2.1345
$(0.6375)^{\star \star}$

$-1.5347$

$(0.7221)^{\star}$

$-1.6442$

$(0.4525)^{\star \star}$

$-2.2155$

$(0.4852)^{\star \star}$

0.2540
$(0.0464)^{\star *}$

0.2552

$(0.0469)^{\star \star}$

0.1802

0.2267

$(0.0275)^{\star \star}$

$(0.0312)^{\star \star}$

0.1093
$(0.0366)^{\star \star}$

\subsection{8}

$(0.0372)^{\star \star}$
0.0069

(0.0274)
$-0.0224$

(0.0313)

Panel B: Dependent Variable: Currency Crisis $(0,1) .1$ if $\operatorname{REE}(t)-R E E(t-1)>15 \%$ - Probit (dF/dX) estimators

1970's GDP per capita

Switching to peg between $\mathrm{t}-2$ to $\mathrm{t}-1$

Switching to float $\mathrm{t}-2$ to $\mathrm{t}-1$

Switching to Capital Controls between t-2 to t-1

Currency crisis at time t-1

Currency crisis at time t-2

Government def $\mathrm{t}-\mathrm{1}^{M}$

Country fixed-effects
0.0000

(0.0000)

0.3125

$(0.0991)^{\star \star}$

0.2893

$(0.1028)^{\star *}$

0.0557

(0.0510)

0.0325

(0.0516)

$-0.2656$

$-0.3313$

$(0.0470)^{\star *}$

$(0.0524)^{\star *}$

0.2299

0.1314

$(0.0377)^{\star *}$

$(0.0349)^{\star \star}$

0.0563

(0.0296)

$-0.0307$

(0.0256)

0.0000

0.0000

(0.0000)

(0.0000)

\section{Note:}

Data includes 106 countries in the years 1970 to 1997

$\wedge$ Currency crisis $=1$ if the real exchange rate increased by $15 \%$ between $\mathrm{t}-1$ to $\mathrm{t}$ (1 STD)

All specifications include linear time trend

( ) Standard errors in parenthesis

* significant at 5\%; ** significant at $1 \%$

No

Yes 
Table 4:

Exchange Regime and Capital Controls: Cyclical and Persistent Effects

\section{Panel A: Dependent Variable: Growth Rates}

Variables

Peg at time t-1

Switching to peg between t-2 to t-1

Switching to float between $\mathrm{t}-2$ to $\mathrm{t}-1$

Capital Controls at t-1

Switching to Capital Controls between t-2 to t-1

The probability of having currency crisis this year ^

\section{Controllers}

1970 GDP per capita

Currency crisis at time t-1

Currency crisis at time t-2

Growth rate at time t-1

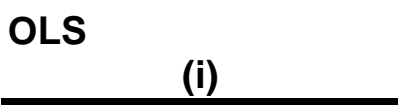

FE

$-0.6088$

$(0.2899)^{\star}$

0.1813

$(0.4787)$
3.9786
4.9046
$(1.2935)^{\star \star}$
$(1.4604)^{\star \star}$
0.4657
(0.7124)
0.8090
(0.8382)

$-1.2843$

$(0.4539)^{\star \star}$

$-1.1997$

(0.9385)

$-1.2843$

$-5.9101$

$(0.4539)^{\star \star}$

$(1.7511)^{\star \star}$

$-7.9131$

(6.0140)

$-13.7764$

$(4.4409)^{\star \star}$

$-0.0013$

$(0.0006)^{\star}$

2.3069

(1.4183)

2.6221

$(0.7543)^{\star \star}$

$-1.7389$

$(0.7269)^{\star}$

$-2.3438$

$(0.4911)^{\star \star}$

0.2481

$(0.0456)^{\star \star}$
0.2247

$(0.0312)^{\star \star}$

\section{Panel B: Dependent Variable: Currency Crisis $(0,1) .1$ if $R E E(t)-R E E(t-1)>15 \%$ - Probit (dF/dX) estimato}

1970's GDP per capita

Peg at time $\mathrm{t}-1$

Switching to peg between t-2 to t-1

Switching to float $\mathrm{t}-2$ to $\mathrm{t}-1$

Capital Controls at t-1

Switching to Capital Controls between t-2 to t-1

Currency crisis at time t-1

Country fixed-effects

$$
\begin{gathered}
0.0000 \\
(0.0000)
\end{gathered}
$$

$$
-0.0192
$$$$
\text { (0.0221) }
$$

0.0368

(0.0361)

$\begin{array}{cc}0.2798 & 0.2106 \\ (0.1029)^{\star \star} & (0.1070)^{\star}\end{array}$

$$
0.0801
$$

(0.0567)

0.1085

(0.0674)

$-0.0383$

(0.0283)

$-0.1021$

(0.0639)

$-0.2491$

$(0.0513)^{\star \star}$

$-0.2820$

$(0.0646)^{\star \star}$

$$
\begin{gathered}
0.2264 \\
(0.0373)^{\star \star}
\end{gathered}
$$

$$
\begin{gathered}
0.1255 \\
(0.0345)^{\star *}
\end{gathered}
$$

No

Yes

\section{Note:}

Data includes 106 countries in the years 1970 to 1997

${ }^{\wedge}$ Currency crisis $=1$ if the real exchange rate increased by $15 \%$ between $\mathrm{t}-1$ to $\mathrm{t}$ ( 1 STD)

All specifications include linear time trend

( ) Standard errors in parenthesis

* significant at $5 \%$; ** significant at $1 \%$ 


\section{Table 5:}

The Effect of Sudden Stop Crisis and

Dollarization (Foreign Liabilities - Money Supply Ratio) on Growth

Variable

Foreign Liabilities - Money Suuply Ratio

(FLM)

Sudden Stop Crisis

Growth at $\mathrm{t}-1$

\section{$\underline{\text { Interaction }}$}

Sudden Stop Crisis * FLM

(i)

$\begin{array}{rrr}0.001 & -0.001 & 0.000 \\ (0.042) & (0.042) & (0.042)\end{array}$

-0.881
$(0.384)$

$-0.781$

(0.378)

0.173

$(0.021)$

$(0.021)$

$-2.384$

(0.931)

Country fixed effect

Yes

2228

Yes Yes

Observations

2228

2228 
Table 6:

The Effect of Sudden Stop Crisis on Dollarization (Foreign Liabilities - Money Supply Ratio)

Variable

(i)

(ii)

(iii)

Crisis at $\mathrm{t}-2$

$(0.020)$

$-0.034$

(0.020)

Peg at time $\mathrm{t}-2$

$\begin{array}{rr}0.042 & 0.010 \\ (0.024) & (0.028)\end{array}$

Capital Controls at t-2

$$
-0.013
$$

$-0.009$

(0.028)

(0.028)

The probability of having currency crisis this year^

$$
\begin{array}{rr}
-0.200 & -0.176 \\
(0.070) & (0.083)
\end{array}
$$

Country fixed effect

Yes Yes Yes

Observations

$1176 \quad 1176$

1176 


\section{Table 7:}

The Effect of Sudden Stop Crisis and

Dollarization (Foreign Liabilities - Money Supply Ratio) on Growth

Variable

Foreign Liabilities - Money Suuply Ratio

(FLM)

Sudden Stop Crisis

Growth at $\mathrm{t}-1$

\section{$\underline{\text { Interaction }}$}

Sudden Stop Crisis * FLM

(i)

$\begin{array}{rrr}0.001 & -0.001 & 0.000 \\ (0.042) & (0.042) & (0.042)\end{array}$

-0.881
$(0.384)$

$-0.781$

(0.378)

0.173

$(0.021)$

$(0.021)$

$-2.384$

(0.931)

Country fixed effect

Yes

2228

Yes Yes

Observations

2228

2228 
Table 8:

The Frequency of Sudden Stop and Domestic Prices Crises

Using Reinhart-Rogoff (2004) Classification ${ }^{*}{ }^{* *}$

\begin{tabular}{|c|c|c|c|c|}
\hline \multirow{5}{*}{$\begin{array}{l}\text { Sudden Stops } \\
\text { Crises }\end{array}$} & & \multicolumn{3}{|c|}{ Domestic Price Crises } \\
\hline & & 0 & 1 & \\
\hline & 0 & 24.6 & 9.9 & 34.5 \\
\hline & 1 & 29.3 & 36.3 & 65.5 \\
\hline & & 53.9 & 46.1 & 100.0 \\
\hline
\end{tabular}

\section{Notes:}

* Reinhart and Rogoff (2002) classified into 5 categories: (i) peg,

(ii) limited flexibility, (iii) managed floating, (iv) freely floating and (v) freely falling.

We aggregate it into 2 main categories: (i) peg_rr, including the first 3 and (ii)

float_rr, including the other two.

** Data includes 58 countries in the years 1970 to 1997

Domestic prices crisis = 1 if the inflation rate is above $20 \%$ per year and 0 otherwise.

Sudden stop crisis = 1 if the real exchange rate depreciation is above $15 \%$ per year and 0 otherwise. 
Table 9:

Switches Between Float and Peg

Using Reinhart-Rogoff (2004) Classification,,**

Variable

Frequency

Switches to peg

10.18

Switches to float

9.97

\section{Notes:}

* Reinhart and Rogoff (2002) classified into 5 categories: (i) peg,

(ii) limited flexibility, (iii) managed floating , (iv) freely floating and (v) freely falling. We aggregate it into 2 main categories: (i) peg_rr, including the first 3 and (ii) float_rr, including the other two.

** Data includes 58 countries in the years 1970 to 1997 
Table 10:

Exchange Regime and Capital Controls

Using Reinhart-Rogoff (2004) Classification ${ }^{*},{ }^{* *}$

Fixed-Effects Estimators

\section{Dependent Variable: Growth Rates}

Variables

Peg at time $\mathrm{t}-1$

Capital Controls at t-1

Switching to Capital Controls between t-2 to t-1

The probability of having currency crisis this year^ excluding the effect of price crisis

The probability of having currency crisis this year - real^^ including the effect of price crisis

\section{Controllers}

Growth rate at time $\mathrm{t}-1$

0.176

(0.034)

0.008

(0.035)

2.812

(0.978)

$-1.904$

(0.479)

$-0.100$

(0.491)

0.385

(0.488)

Price (CPI) crisis at time $\mathrm{t}-1$

Price $(\mathrm{CPI})$ crisis at time $\mathrm{t}-2$

Currency crisis at time t-2

Price (CPI) crisis at timet-2 (ii)

(iii)

1.729

(0.565)

$(0.549)$

0.156

(1.022)

$-0.587$

(0.991)

$-6.155$

(1.518)

$-22.359$

$-6.824$

7.632

(4.084)

(6.578)

0.191

0.183

(0.034)

(0.034)

0.022

0.019

(0.035)

(0.035)

0.917

3.340

(0.629)

(1.069)

$-1.804$

$-1.831$

(0.483)

1.078

(0.772)

$-1.251$

\section{Notes:}

* Reinhart and Rogoff (2002) classified into 5 categories: (i) peg, (ii) limited flexibility, (iii) managed floating

, (iv) freely floating and (v) freely falling. We aggregate it into 2 main categories: (i) peg_rr, including the first 3 and (ii)

float_rr, including the other two.

** Data includes 58 countries in the years 1970 to 1997

$\wedge$ The estimated the likelihood for a currency crisis ignoring the effect of price crisis.

$\wedge \wedge$ The estimated probability for a currency crisis including the effect of past price crisis

All specifications include linear time trend

( ) Standard errors in parenthesis 
Figure 1:

The Marginal Effect of Switiching from Float to Peg on Growth

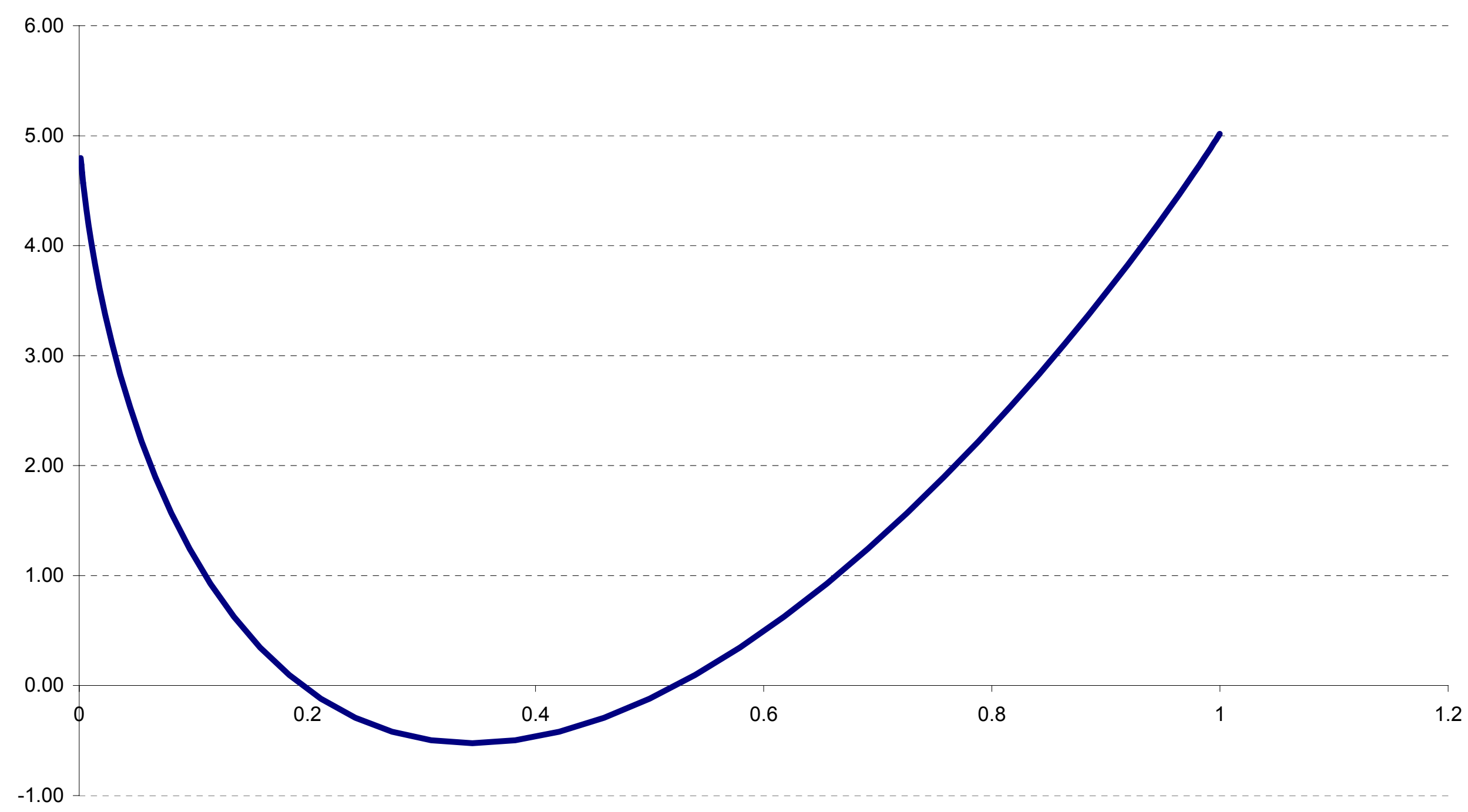


Figure 2:

The Marginal Effect of Liberalization in Capital Controls on Growth

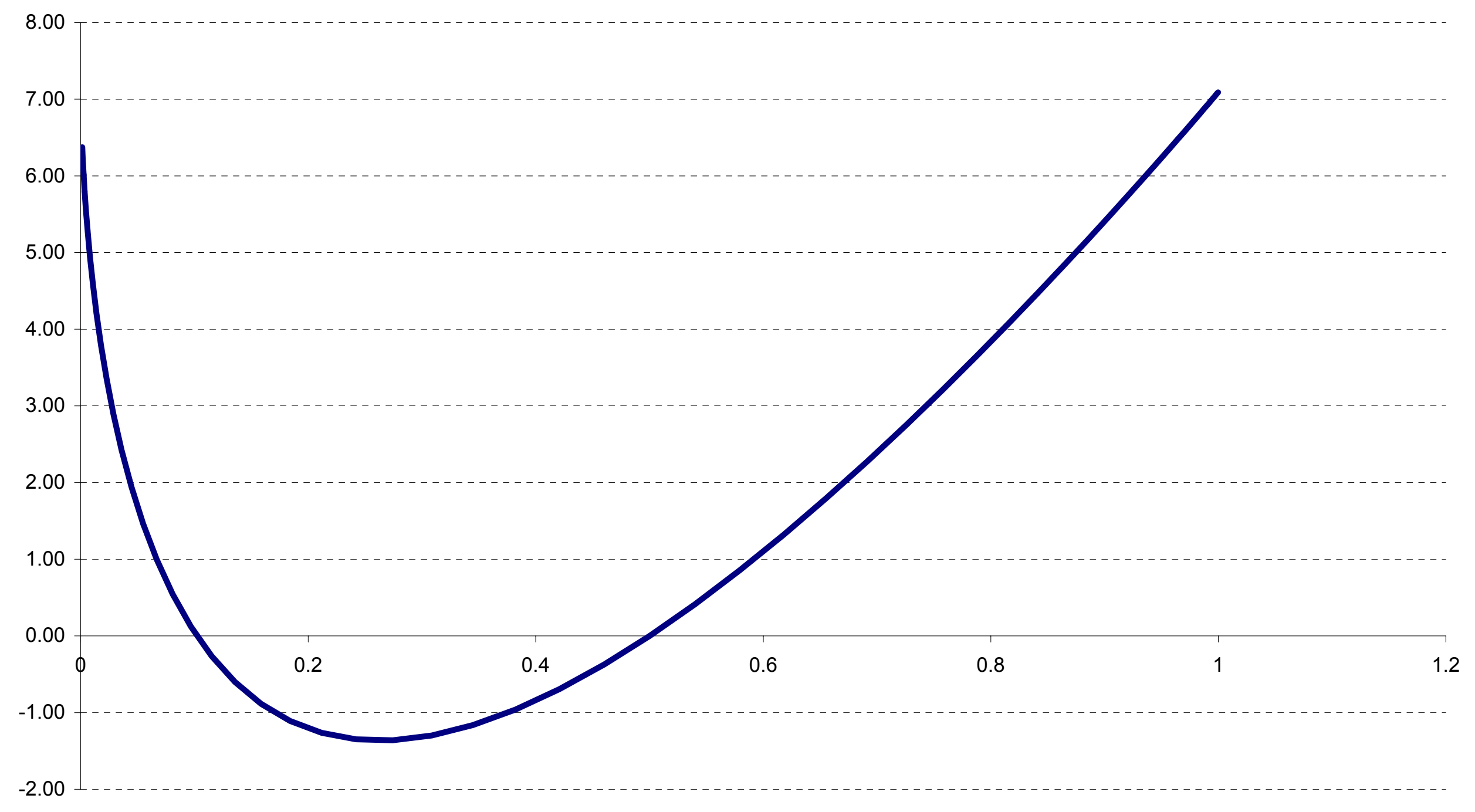


Figure 3:

Switching from Float to Peg with and without Capital Controls

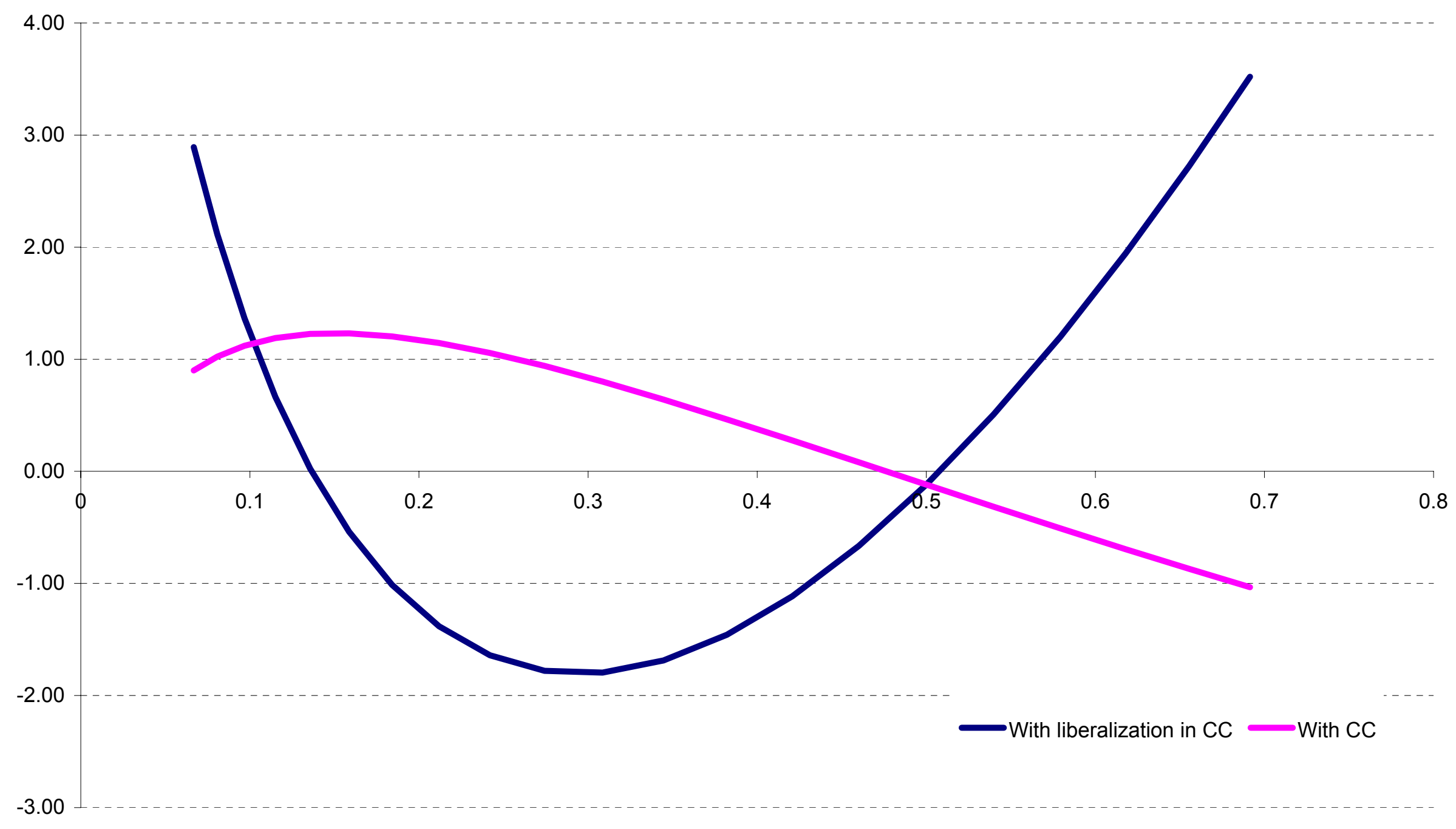


Figure 4:

The Marginal Effect of Switiching from Float to Peg on Growth by The Foreign Liabilities - Money Suuply Ratio

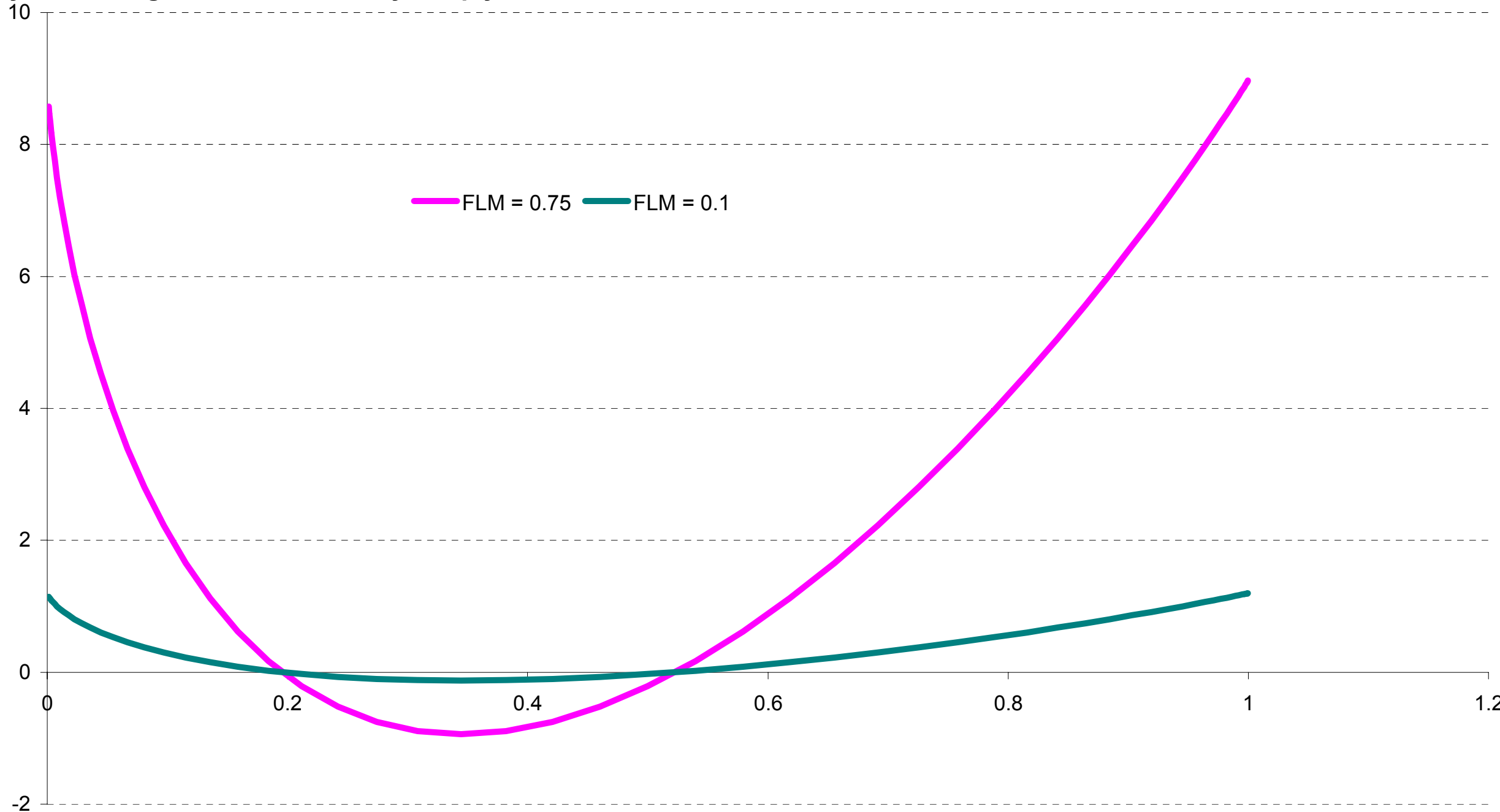

